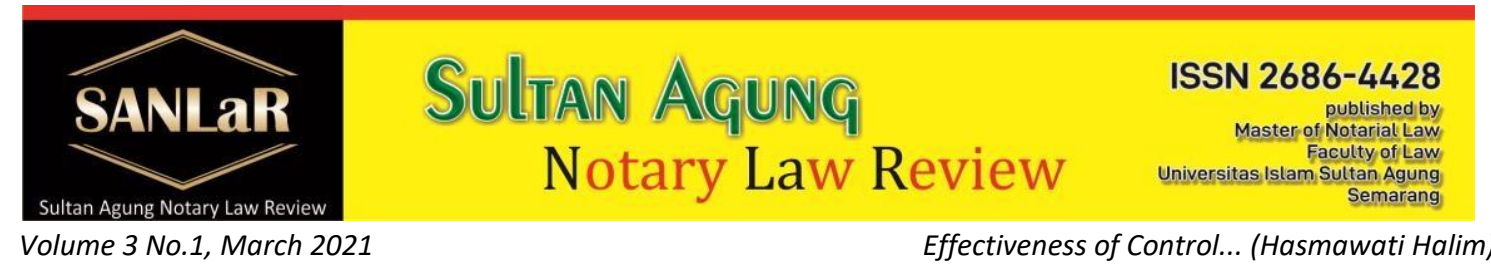

\title{
Effectiveness of Control of Deep Agricultural Soil on Enrollment Perspective
}

\author{
Hasmawati Halim*) \\ *) Student Master of Notary Law, Faculty of Law, Universitas Islam Sultan Agung \\ Semarang, Indonesia, E-mail: hasma.halim212@gmail.com
}

\begin{abstract}
The objectives of this study were to: 1) Know why control over control of agricultural land has not been effective, 2) to know how to control of agricultural land through land registration. The data used in this study are primary data and secondary data that can support the assessment, which is then analyzed using qualitative methods with descriptive purposes. Based on the results of data analysis, it is concluded that: 1) Control of control over agricultural land in the perspective of land registration is less effective, this is due to conflicts of interest between the government, economic demands and a lack of understanding by the community that the importance of agricultural land for food security, which results in many agricultural lands being converted to non-agricultural land. In this case, BPN/ATR could not do much because of the constraints on land conversion permits issued by the local government. 2) Dominant factors causing Government Regulation Number. 24 of 1997 concerning Land Registration from a juridical perspective that there is no regulation regarding sanctions if land owners do not register their land. So that government supervision through BPN/ATR in the context of controlling control of agricultural land becomes less effective.
\end{abstract}

Keywords: Agricultural Land; Control System; Land Registration.

\section{Introduction}

Indonesia is a country where most of the population makes a living in agriculture (Agraris) and Southeast Sulawesi is one of the areas in Indonesia where one of the districts, Konawe, makes agriculture a livelihood land for most of the population, both as owners of agricultural land, as smallholders and farmworkers. Land is a very important factor for the survival of society and the development of a nation. The importance of land for human life is something that cannot be separated because human survival to obtain food is mostly derived from land management.

For the people of Indonesia, land has a deeper meaning than just a commodity, land is seen as a gift that is used maximally for the survival of the people towards the prosperity and welfare of the nation however, land problems often arise which are one of the consequences of increasing development in the current era. One of the contributing factors is the difference in community interests, especially in the land sector. Differences in interests that result in problems in the land sector in society, both between individuals, individuals and the government will continue in line with the increasing need for land. Land problems that often occur today are usually related to 
the legal certainty of land rights. ${ }^{1}$ To be able to achieve this purpose, the land needs to be regulated for optimal control, use and utilization. Therefore, the rate of land use needs to be controlled so that the function of the land will be for the welfare of the community. Of course, this effort must be considered continuously considering the need for land which is always increasing continuously for use by the community.

The increasing need for land has resulted in a lot of agricultural land being converted into non-agricultural land to meet these needs, as for one of the government's efforts to control the control of agricultural land, namely through land registration, but in its implementation there are still many people who commit irregularities in terms of owning agricultural land. Efforts often occur, one of which is to transfer land ownership by way of selling and buying under hand which results in transfers that are not registered at the Office of the National Land Agency so that they are separated from the supervision of the land office, this is a result of the lack of public awareness of the importance of land registration, this is regulated in Government Regulation Number. 24 of 1997 concerning land registration.

The increase in population and the need for land ownership has led some people to do things that are not wise in owning or controlling land, this has also led to some agricultural land being converted into non-agricultural land in an effort to meet the community's need to own land. This is done without paying attention to the consequences of the conversion of agricultural land to non-agriculture which will cause a reduction in agricultural land which is intended to ensure food security, in accordance with the objectives of the Minister of Agrarian Regulation No. 18 of 2016 Article 2 paragraph (1): "Which has the Purpose and Objectives to reduce social inequality, equalize the welfare of society and ensure food security". ${ }^{2}$

\section{Research methods}

The writing of this thesis using the sociological juridical research method is a study conducted on the real situation of society with the intent and purpose of finding facts then towards problem identification and ultimately problem solving, sociological juridical research methods are used to analyze and provide answers to legal problems according to the target which is aimed. ${ }^{3}$ while the juridical factor is based on the applicable legal provisions relating to Control of Control over Agricultural Land in Konawe Regency.

\section{Results and Discussion}

\subsection{Not Effective Agricultural Land Control}

Land is a natural resource which is limited in number and in which the amount will not increase, therefore in its utilization it must prioritize the interests of mankind so that

1 Bahtiar, Efendi. (1993). Kumpulan Tulisan Tentang Hukum Tanah. Bandung: Alumni. p. 5

2 htps;//Jurnal.Narotama.Ac.Id/Index.Php/Tsl/Article/Download/472/275 accessed on 18 August2020, at 19.00 WITA.

3Ashshofa, Burhan. (2007). Metode Penelitian. Semarang: Media Press. p.46. 
what the State aspires to be achieved for the welfare of the people in a State. This is in accordance with the mandate in the 1945 Constitution as stipulated in Article 33 paragraph (3) which reads:

"The land and water and natural resources contained therein are controlled by the State and used for the greatest prosperity of the people." Therefore, land is a natural resource that is part of the earth's surface, so the land in its allocation must pay attention to the welfare of the people. ${ }^{4}$

Kownership and control of agricultural land is regulated in Article 2 paragraph (1) Regulation of the Minister of Agrarian Affairs and Spatial Planning/Head of the National Land Agency of the Republic of Indonesia Number 18 of 2016 concerning control over control of agricultural land which states that the purpose and objective of implementing this regulation is to reduce social disparities, equalizing community welfare and ensuring food security. ${ }^{5}$

In order to determine the effectiveness of control of agricultural land tenure in the perspective of land registration, the authors took a sample in Konawe District, Southeast Sulawesi. The author conducted an interview with the Konawe Regency National Land Agency. According to the Head of the Section for Law and Public Relations, Mr. Muchtar and Mr. Salahuddin Alanzar, ownership and control of agricultural land which is converted into non-agricultural land as regulated in statutory regulations is not allowed, considering that land is Natural resources which are essential for human survival and the land itself is a limited natural resource.

The next writer carried out the research by giving questionnaires to several random people in Konawe Regency. The author provides several questions related to this research through a questionnaire containing 6 (six) questions related to this research, as for the reasons for giving a community questionnaire with simple questions followed by multiple choice answers in order to make it easier for people to answer according to their knowledge.

From the questionnaire, information can be drawn that legal counseling has not been effective for controlling control of agricultural land as expected because it has not reached all groups, there are still many people who feel that they have never heard of or participated in legal counseling about land which has resulted in a lack of public understanding of the conversion of agricultural land, that There are regulations that prohibit the conversion of agricultural land to non-agricultural functions, such as property or industrial land. Another problem arises from the influence of customs where people prefer to own or control land through underhand buying and selling transactions because they feel it is more efficient and easy on the other hand, the community's lack of understanding of the procedures for land registration resulted in the transfer of land ownership being escaped from BPN's supervision. Among the 31

4 Constitution of 1945, Article 33 Paragraph (3)

5 Snaeni, Diyan. (2017). Kebijakan Program Redistribusi Tanah Bekas Tambang Dalam Menunjang

Pembanguanan Sosial Ekonomi Masyarakat, Jurnal Masalah-Masalah Hukum. Vol 46. No. 4 
residents who filled out the questionnaire, 9 of them could not read and write, so I as a researcher took the initiative to read out the right to the questionnaire so that 9 residents could answer some of the questions I asked, in this case I helped fill in their answers according to their answers. This makes the authors conclude that the level of education also influences people's understanding of controlling control of agricultural land. Among the 31 residents who filled out the questionnaire, 9 of them could not read and write, so I as a researcher took the initiative to read out the right to the questionnaire so that 9 residents could answer some of the questions I asked, in this case I helped fill in their answers according to their answers. This makes the authors conclude that the level of education also influences people's understanding of controlling control of agricultural land. Among the 31 residents who filled out the questionnaire, 9 of them could not read and write, so I as a researcher took the initiative to read out the right to the questionnaire so that 9 residents could answer some of the questions I asked, in this case I helped fill in their answers according to their answers. This makes the authors conclude that the level of education also influences people's understanding of controlling control of agricultural land.

Constraints faced in the field in controlling control of agricultural land are due to the existence of a Regional Spatial Plan (RTRW) in which there are efforts to grant location permits, location permits are the main instruments in controlling to prevent conversion/change of function of technically irrigated agricultural land. Because in reality, many RTRWs actually plan to convert or change the function of land/technical agricultural land to non-agricultural.

Another weakness in the existing laws and regulations, namely, the object of agricultural land which is protected from the conversion process is determined based on the physical condition of the land, even though the physical condition of the land is relatively easy to manipulate, so that land conversion can take place without violating applicable regulations. The existing regulations tend to be an appeal and do not establish clear and clear sanctions, both the size of the sanctions and the determination of the party being sanctioned.

On the one hand, the regulation aims to protect the conversion of agricultural land, but on the other hand, the government encourages industrial growth, which in fact occurs in good resources (agriculture). These regulations are only implementing, but not followed by control and enforcement of the rule of law. In this way the regional apparatus made gaps to gain instant advantage. The existing regulations tend to only prohibit the transfer of use of agricultural land, without providing an alternative solution.

\subsection{Control of Control over Agricultural Land through Registration}

Legal awareness has a correlation with law obedience or legal effectiveness and automatically citizens obey the applicable law. When community members behave in accordance with what is expected or desired by law, it can be said that the existing law has been effective. Legal certainty of land ownership requires active participation from 
the community in its enforcement, which currently has a low level of community awareness.

Land in a country cannot be owned, controlled and used freely by humans, the state has the right to regulate the existence, ownership and use of land. The arrangement and management of land by the state is possible from one country to another. ${ }^{6}$ Control of land is generally controlled by the state as regulated in Article 33 paragraph (3) of the 1945 Constitution which states that:

"The earth and water and the natural resources contained therein shall be controlled by the state and used for the greatest prosperity of the people".

Land registration in Indonesia is carried out based on the provisions of Article 19 UUPA enhanced by Government Regulation Number 24 of 1997 concerning Land Registration and Regulation of the State Minister for Agrarian Affairs/Head of the National Land Agency Number 3 of 1997 concerning Implementing Provisions for Government Regulation Number 24 of 1997 concerning Land Registration.

Many farmers who own land and cultivate them without having a title of ownership and do not know the layout of their land, which is a green area, has been converted into housing or industry, and this has become a problem in the land sector. The phenomenon of land use change has become a matter of concern and has become a wetland for offenders who take advantage of agricultural/plantation owners who trade their land to non-residents, and at the time of registering the transition at the Land Office is rejected because agricultural land must be processed by local residents.

Empirical literature that examines the impact of violations that occur in the community in the form of a certificate of the function of agricultural/plantation land into homestead so that it is separated from monitoring of land use change. This situation is also due to the absence of an integrated system between BPN and Pemprov regarding RTRW specifically for agricultural areas. The test results show that violations of land use change are significantly influenced by the demands of the community who want to easily transfer land rights accompanied by the conversion of land functions that should be agricultural areas into housing or industrial areas, as well as support from individuals who provide an easy way to register land.

Based on the description above, efforts to direct policies in the making of legislation (law making) and law enforcement in the land sector and the local government of Konawe Regency are not implemented properly and are not coordinated. Land, which is a very important factor for the community and the State, must also adapt to the needs of the community and the interests of the State, which demands legal certainty over land rights so that the exercise of authority from said land rights can take place properly. However, there are many changes in the function of agricultural land that can be registered at the Land Agency with a certificate from the local government.

6 Hartanto, Andy. (2014). Pemilikan Hak Atas Tanah Di Indonesia. Surabaya: Laksbang Justisia. p. 13. 
Goodwill from the community to take part in the effectiveness of the Control of Land Ownership, which requires awareness and participation of the community regarding the importance of land registration for orderly administration, as well as the good faith of the community not to convert their agricultural land to non-agriculture for mutual welfare and to help achieve Food security as desired. - tell me the nation.

\section{Closing}

\subsection{Conclusion}

1. Control of control over agricultural land in the perspective of land registration is less effective, this is due to conflicts of interest between the government, economic demands and a lack of understanding by the community that the importance of agricultural land for food security, which results in many agricultural lands being converted to non-agricultural land. In this case, BPN/ATR cannot do much because of the constraints on the land conversion permit issued by the local government.

2. The dominant factors that led to Government Regulation No. 24 of 1997 concerning Land Registration from a juridical perspective that there is no regulation regarding sanctions if land owners do not register their land. So that government supervision through BPN/ATR in the context of controlling control of agricultural land becomes less effective.

\subsection{Suggestions}

1. As the flow of investment in Indonesia increases, the intensity of conflicts over the use of agricultural land will be increasingly dilemmatic considering that the expansion of agricultural land is already very limited, while population growth is increasing and demands for land needs for property and the industrial sector are increasing and it is impossible to avoid in line with regional economic growth if this situation is not immediately resolved with a land policy, the sustainability of the land system will be disrupted. Realizing this problem, the government, in this case BPN/ATR and the Ministry of Agriculture, need to coordinate with each other in determining the basic map of land, especially agricultural land, as well as stipulating regulations on prohibiting the status of agricultural land to non-agricultural land.

2. There is a need for further collaborative supervision of BPN/ATR and the Ministry of Agriculture to actively coordinate the problem of conversion of agricultural land so that control over control of agricultural land can be effective and increase public understanding through legal counseling about land, especially regarding control over control of agricultural land and the importance of land registration, so that in These efforts are expected to increase public legal awareness.

\section{References}

\section{Journal:}

Snaeni, Diyan. (2017). Kebijakan Program Redistribusi Tanah Bekas Tambang Dalam Menunjang Pembanguanan Sosial Ekonomi Masyarakat, Jurnal Masalah-Masalah Hukum. Vol 46. No. 4

Books:

[1] Ashshofa, Burhan. (2007). Metode Penelitian. Semarang: Media Press. 
[2] Bahtiar, Efendi. (1993). Kumpulan Tulisan Tentang Hukum Tanah. Bandung: Alumni.

[3] Hartanto, Andy. (2014). Pemilikan Hak Atas Tanah Di Indonesia. Surabaya: Laksbang Justisia.

\section{Regulations:}

[1] Constitution of 1945, Article 33 Paragraph (3)

[2] Government Regulation No. 24 of 1997 concerning Land Registration Internet:

htps;//Jurnal.Narotama.Ac.Id/Index.Php/Tsl/Article/Download/472/275 accessed on 18 August 2020, at 19.00 WITA. 